\title{
Analysis of Awareness on Biogas Adoption as the Alternative Energy through the Blue Economy Concept Application
}

\author{
Nurul Istiqomah ${ }^{1 *}$, Izza Mafruhah ${ }^{2}$, Dewi Ismoyowati ${ }^{3}$ and Nunung Sri Mulyani ${ }^{4}$ \\ 1,2,3,4 Fakultas Ekonomi dan Bisnis, Universitas Sebelas Maret, Indonesia
}

\begin{abstract}
Objective - The purpose of this study is (1) to analyse community perception in the use of biogas as an alternative energy, (2) to analyse whether variables such as income, age, education, cost savings, and livestock maintenance costs actually affect the willingness of community to use biogas, and (3) to develop a relationship among potential regional resources in the blue economy development.

Methodology/Technique - The method used in this study is a collaboration between quantitative and qualitative models. For the first research objective, the qualitative theory approach focused on in-depth interviews and focus group discussions to develop a variety of potential economic relations in the implementation of the blue economy. For the second objective, descriptive statistics was used to identify differences in community perceptions on the use of biogas by the people in the Ngawi and Boyolali regencies. For third objective, model is used to analyze whether income, age, education, cost savings, and livestock maintenance costs affect community willingness to use biogas:

Findings - The results show that (1) there are different community perceptions on biogas adoption in the Ngawi and Boyolali regencies, (2) variables such as income, age, education, cost savings, and livestock maintenance costs affect the willingness of community in using biogas, and (3) the blue economy concept can be developed by utilizing economic potentials in Ngawi towards an energy-independent village.

Novelty - The use of biogas as an alternative energy needs to be developed so as to stimulate influential variables that can raise public awareness because the method is simple and exploits local potentials without waste.
\end{abstract}

Type of Paper: Empirical

Keywords: Blue Economy; Public Awareness; Logit Regression; ABCG actors.

JEL Classification: P28, P43.

\section{Introduction}

Energy is one of the input used in industries, services, transport, and household activities. Energy can be derived from non-renewable and renewable sources. Indonesia was once known as an energy producer of oil and natural gas. However, over the years, the depletion of oil reserves and an increased fuel consumption had led Indonesia to become a net oil importer since 2004. Efforts in saving energy for the supply of fuel derived from petroleum, gas or coal is diminishing while demand continues to rise. This phenomenon calls for the

\footnotetext{
Paper Info: Received: October 2, 2016

Accepted: December 19, 2016

* Corresponding author:

E-mail: nurulistiqomah1980@yahoo.com

Affiliation: Fakultas Ekonomi dan Bisnis, Universitas Sebelas Maret, Indonesia.
} 
development of alternative renewable and environmental friendly energy. This initiative is required because of global warming and the declining quality of the environment. The development of alternative renewable and environmental friendly energy that is locally available can be an instrument of many benefits such as reducing dependence on fossil energy, realizing environmental sustainability and providing energy that is easily accessible to the local community in terms of quantity, quality, and purchasing power (Setyawan, 2010).

According to the National Energy Policy Blue Print, in 2006, the energy source was still dominated by oil - $53 \%$, followed by coal and natural gas $-22 \%$ and $21 \%$ respectively while other energy is only about $4 \%$. It is expected that by 2025 , oil use will have been reduced to $20 \%$ and other energy derived from geothermal, coal liquefaction, biofuel, nuclear, CBM, biomass, and hydrogen will have increased to 17\%. (ESDM, 2005).

The average energy consumption in Indonesia increases about 7-8\% per year while the economy grows about 5-6\% percent per year resulting in energy elasticity of about 1.6 and this implies an inefficient use of energy. The figure is far above the elasticity level in developed countries such as Japan and the United States where elasticity is 0.1 and 0.2 respectively. Compared to ASEAN countries like Singapore and Thailand that have slightly higher levels with 1.1 and 1.4 respectively, the disparity clearly stands out. This indicates that the use of energy in Indonesia requires revamping, standing at 1.6.

One way to save fuel is to reduce the use of unrenewable energy and to find new renewable energy sources. Some renewable energy sources that are environmental friendly are available at the local level. One of them is biogas, the energy that comes from gases produced by anaerobic or the fermentation process of organic materials derived from manure, household waste, and animal waste. Galvez et al., (2015) stated that biogas is a source of potential energy that can be used for the continuity of sustainable development.

The concept of green economy has begun to shift to the blue economy, a concept that implements social inclusiveness, natural resources efficiency, and zero waste production systems. Blue economy is an economic concept that was developed to meet the challenges of the world economic system that tends to be exploitative and damaging to the environment. The main damage is caused by waste and over-exploitation. The main motto of the Blue Economy concept is zero waste (Bogdan, 2014).

Biogas, which is derived from cow dungs, especially beef cattle and dairy cows, is one of the alternative energies that can be used for the blue economy application. In 2015, the number of beef cattle in Indonesia was 15,494,288 with East Java Province having the highest number of 4,326,261 followed by Central Java Province with 1,628,093. Meanwhile, the dairy cow population was 525,171 with East Java having the largest population with 253,830 followed by West Java, with 135,345.

The blue economy concept could be applied in the MSME industrial centers which include tempeh chips industrial centers in Karang Tengah, Ngawi district, East Java province. If soybeans, the main ingredient of tempeh chips and its waste are used as cattle feed, the feeding expenses, which is constantly increasing, can be reduced. In addition, cow dungs can be collected and used as biogas for cooking. Based on observations, the tempeh chip frying process is largely fueled by wood taken from forests around Ngawi. This causes the production site to become dirty, polluting the air at the same time and indirectly, driving small-scale illegal logging. The biogas produced can be used as fuel for cooking or frying the chips and this can reduce production costs and increase profits. It is expected that the process of tempeh chip production will generate zero waste since soybean dregs are being used as cattle feed, cow dungs as biogas, and biogas as fuel for cooking.

Waste as biogas raw materials is found in rural areas, particularly those producing organic waste and livestocks. The government has sought to develop biogas at the community level but community awareness remains underdeveloped. In light of these problems, the objective of this paper is to develop the economic potential relationship between the advantages of biogas utilization and the awareness for the blue energy implementation and to analyse community perception, particularly micro-scale entrepreneurs and households, in the use of biogas as an alternative energy.

\section{Literature Review}


There are two types of energy: renewable energy and non-renewable energy. Renewable energy is energy that can be recovered and it comes naturally from the sun, wind, water, and biofuels that can be produced repeatedly. Renewable energy sources are always there and it does not damage the environment because it is categorized as clean energy. Sources of energy coming from the sun, wind, biomass, and water are the most suitable energy for use in remote or rural areas. The potential renewable energy source that has not been used optimally is biogas.

The concept of the Blue Economy, in essence, is to create zero waste and answer the threat of food insecurity and energy crisis. Its main goal is to transform poverty to prosperity and scarcity to abundance. This concept is designed for sustainable development with the efficient use of natural resources so as to not damage the natural system. The waste generated in the production process is used as raw material for other products, so that the waste can produce a variety of other products and revenue. The blue economy concept is a policy that is pro-poor, pro-jobs, pro-growth and pro-environment.

According to the International Energy Agency (IEA), biogas is the energy derived from natural processes that can be refilled continuously. Biogas can be derived from animal waste, agricultural waste, and organic waste that has methane gas content of $\pm 60 \%$, carbon dioxide of $\pm 38 \%$, and other of $\pm 2 \%$. Biogas is one type of biomass energy with the energy being obtained from plants, animals, and other microorganisms. (Havukainen et al., 2014). Utilization of farm wastes, particularly cow manure, supports the blue energy program or zero waste concept in order to realize sustainable farming systems and environmental friendly economy. Some of the advantages of manure as biogas producers are:

1) It reduces environmental pollution to water, soil, and air,

2) It creates alternative energy for households,

3) It improves the welfare of farmers due to reduced household energy costs; and

4) It creates a Clean Development Mechanism (CDM) (Waskito, 2011).

According to a research conducted by Setyawan (2010), the development of biogas is one form of alternative solution to fossil energy crisis at the local and national levels. Biogas development in Indonesia is in line with the meat self-sufficiency program where increased production of beef will yield abundant cow manure waste as gas fuel. Gebreegziabher et al. (2014) stated that the waste can be utilized and it can be produced economically, thereby adding value. Good waste management is required for improving the quality of the environment and health in developing countries, particularly in rural areas.

Galvez et al., (2015) stated that biogas is a potential source of energy that can be used for the continuity of sustainable development. The first stage in the process of biogas utilization is the decision to build a network/channel to distribute the biogas. This decision is taken by using the AHP as the decision-making process can be complex since it includes economic, social, and environmental factors. At the end of the process, waste producers become aware of the importance of sorting and grouping garbage so that the use of waste as an alternative energy source can be done effectively.

Demarest et al., (1993) had described the influence of socio-economic characteristics on biogas technology. Naming some of these characteristics as income, education level, occupation of the head of household, the amount of waste/manure, and access to water, they claim that all of these can impact on biogas technology adoption. In Uganda, the factors that influenced the adoption consists of age of the household head, household size, traditional fuel used, and education level. It appears that an increase in age and education level is inversely proportional to the willingness to adopt biogas. However, the availability of traditional fuels and household size can positively affect the willingness to adopt biogas. A socio-economic survey conducted in Uganda and Kenya showed that low level education and income are the main causes limiting women to the access of making decisions in using biogas as an alternative fuel. In Kenya, farm size, land ownership security, the amount of milk produced, agricultural systems, and livestock maintenance cost showed a positive correlation with the use of biogas. 


\section{Research Methodology}

The method used in this study is a collaboration between quantitative and qualitative models. For the first research objective, qualitative theory was used with in-depth interviews and focus group discussions to develop a variety of potential economic relations in the implementation of the blue economy. For the second objective, descriptive statistics was used to identify differences in community perceptions on the use of biogas by the people in the Ngawi and Boyolali regencies. For the third objective, the following model is used to analyze whether income, age, education, cost savings, and livestock maintenance costs affect community willingness to use biogas:

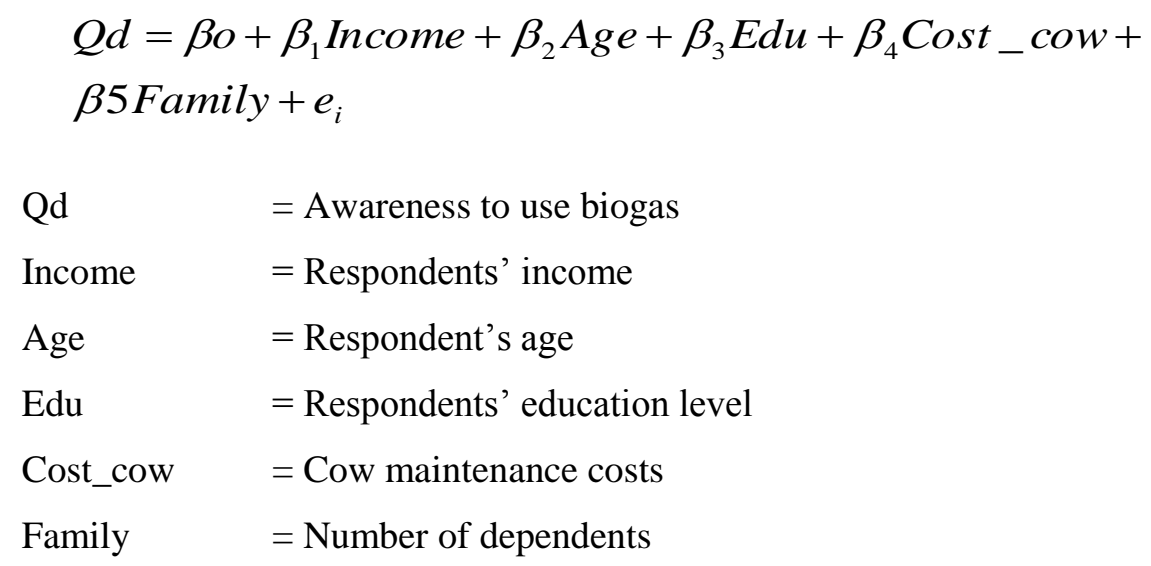

\section{Results}

The development of renewable energy is divided into two: (1) alternative energy that are high investment, large-scale production, and high technology with high cost consequence, which will be built by the government, and (2) alternative energy based on local wisdom, and this alternative energy model is already being applied using local resources as an approach. This model gives a positive value especially in community self-sufficiency by exploiting the potentials of the surrounding environment. The blue economy concept, with the main motto of creating an economy with zero waste will inform the community that virtually, all input, output, and waste noted in the production process will be optimally utilized, if appropriately managed.

The Sadang village in Ngawi, where the research was conducted, is a rural area that served as a pilot model for the Energy Independent Village. It was noted that the government and various stakeholders of the community had not used the biogas digester optimally. Field data showed that $66.67 \%$ of respondent households were using digesters while $33.33 \%$ were not because they thought the application was complicated. Seen from the education aspect, respondents who did not use the biogas digester were primary school graduates. Average savings gained through the use of biogas was IDR 108 750, with an average use of three hours per day. Meanwhile, the use of the biogas digester by business players have not been optimal, especially for tempeh chips producers because the heat power generated is limited to the production process only.

Some of the advantages of biogas adoption noted in the research area include savings where respondents were not required to spend money to buy gas and ultimately, such money could be allocated for other needs. In addition, alternative energy will be able to significantly contribute to the saving of the environment and so improve community welfare as household expenses are indirectly reduced.

The community's willingness to use biogas can be analyzed by using logit regression. Table 1 shows the results of the logit regression analysis. 
Table 1. Results of Logit Regression Analysis

\begin{tabular}{|c|c|c|c|c|}
\hline \multicolumn{2}{|c|}{ Dependent Variable: QD } & & & \\
\hline \multicolumn{5}{|c|}{ Method: ML - Binary Logit (Quadratic hill climbing) } \\
\hline Variable & Coefficient & Std. Error & z-Statistic & Prob. \\
\hline $\mathrm{C}$ & 7.064944 & 13.93895 & 0.506849 & 0.6123 \\
\hline LOG_INCOME & -1.358844 & 2.229497 & -0.609485 & 0.5422 \\
\hline AGE & 0.041711 & 0.051753 & 0.805969 & 0.4203 \\
\hline EDU & 0.282421 & 0.115788 & 2.439114 & 0.0147 \\
\hline LOG_COST_COW & -0.083812 & 0.163392 & -0.512953 & 0.608 \\
\hline FAMILY & -0.229577 & 0.380538 & -0.603294 & 0.5463 \\
\hline McFadden R-squared & 0.171297 & \multicolumn{2}{|c|}{ Mean dependent var } & 0.74 \\
\hline S.D. dependent var & 0.443087 & \multicolumn{2}{|c|}{ S.E. of regression } & 0.427793 \\
\hline Akaike info criterion & 1.189788 & \multicolumn{2}{|c|}{ Sum squared resid } & 8.052295 \\
\hline Schwarz criterion & 1.41923 & \multicolumn{2}{|c|}{ Log likelihood } & -23.74469 \\
\hline Hannan-Quinn criter. & 1.277161 & \multicolumn{2}{|c|}{ Restr. log likelihood } & -28.65285 \\
\hline LR statistic & 9.816312 & \multicolumn{2}{|c|}{ Avg. log likelihood } & -0.474894 \\
\hline Prob(LR statistic) & 0.08061 & & & \\
\hline Obs with Dep $=0$ & 13 & $\begin{array}{l}\text { Total } \\
\text { obs }\end{array}$ & & 50 \\
\hline Obs with Dep $=1$ & 37 & & & \\
\hline $\begin{array}{l}\text { Source: Data Analysis } \\
\text { Output }\end{array}$ & & & & \\
\hline
\end{tabular}

As can be seen, the processed data show that the odds ratio is sought beforehand. Odds ratio is a measure of the magnitude of the effect of the independent variable change on the dependent variable. Table 2 shows the results of the calculation of odds ratios of each coefficient:

Table 2. Odds Ratio Value Using Variables That Affect Biogas Adoption Willingness

\begin{tabular}{|l|c|c|c|}
\hline \multicolumn{1}{|c|}{ Variable } & Coefficient & Odd Ratio & Probability \\
\hline C & 7.064944 & 84.46692627 & 0.6123 \\
\hline LOG_INCOME & -1.358844 & 71.97862331 & 0.5422 \\
\hline AGE & 0.041711 & 52.24182126 & 0.4203 \\
\hline EDU & 0.282421 & 1.480857637 & 0.0147 \\
\hline LOG_COST_COW & -0.083812 & 83.67542144 & 0.608 \\
\hline FAMILY & -0.229577 & 72.68518312 & 0.5463 \\
\hline
\end{tabular}

Source: Data Analysis Output (2016)

Based on the analysis, it can be said that the only variable that affects a person's willingness to use biogas is education. Education variable has a coefficient of 0.282421 with a probability value of 0.0147 . Therefore, it can be concluded that the education variable, at the significant level of $10 \%$, influences the community's awareness on the use of biogas. The odd ratio values of the education variable are 1.4809 , hence, it can be concluded that if a person's level of education increases by one year, the awareness for the use of biogas as an 
alternative energy will increase by $1.48 \%$. Thus, education has an important role to play as the higher the educational level, the more extensive the knowledge and insight of a person. Awareness of the use of biogas is the result of the knowledge about the energy crisis that is occurring in the world and Indonesia which affects sustainable living.

From the data, it also appears that income, age, cow maintenance costs, and the number of family dependents provided no significant effect on the awareness to use biogas as an alternative energy. The higher the income level, the higher the purchasing power of a person to purchase energy (LPG) to meet his/her needs. when this occurs, the individual seems to ignore the idea of taking advantage of biogas as an alternative energy.

Based on research conducted, Roessali et al., (2013) noted that as many as 53.33\% of farmer respondents in Yogyakarta had recognized the urine as a fertilizer and biogas technology but only $3.33 \%$ of them were applying these methods in the business environment. They were aware of the need to convert biogas into alternative energy but they admitted that it was difficult to implement because of the high cost of biogas installation fees and the huge amount and quantity of cow dungs needed to properly activate the biogas process. Thus, it is concluded that a person's awareness in using biogas as one of the alternative energy needs to be built through intensive dissemination by focusing on the added value that will be gained by the community.

\section{Conclusions and Recommendations}

It appears that the use of fossil energy remains to be dominant at present. It was deduced that respondents noted that there were problems in getting enough supply to activate biogas technology. Besides that, there were also problems with the distribution channels, infrastructure, and access equality. Therefore, if alternative energy is needed to reduce dependence on fossil energy and to provide electricity for local and regional levels, the government needs to do more. Clearly, the respondents of Indonesia were deterred by the education variable that affected the Indonesian people's awareness in using biogas as an alternative source of energy.

Biogas as an alternative energy requires community dissemination so that people's awareness to use cattle dungs for sustainable living is a necessity rather than a compulsion. Technological assistance and mentoring are also required in order to successfully implement the blue energy and the Clean Development Mechanism programs towards energy availability saving and community welfare improvement.

\section{References}

Bogdan, A. (2014). New Holistic Approach of Bioeconomics and ecoeconomics Theories, Practical Bringing From The Green Economy to Blue Economy, Trough New Integrated and Innovative Paradigm About Bio-Eco-GeoEconomy. Procedia Economics and Finance 8 83-90.

Damanik, Latifah Hanum. (2014). Pemanfaatan Feses Ternak Sapi Sebagai Energi Alternatif Biogas Bagi Rumah Tangga dan Dampaknya Terhadap Lingkungan. Jurnal Teknosains Volume 4. No 1. Desember 2014. Halaman 54-63.

Demarest EJ, Reisner ER, Anderson LM, Humprey DC, Farquhar E, Stein SE. (1993). Review of Research on Achieving the Nation's Readiness Goal. Washington D.C: U.S.Department of Education; 1993. p. 82.

Dianawati M. (2014). Penggunaan Limbah Organik Biogas Sebagai Media Tanam pada Produksi Benih Kentang (Solanum tuberosum L) GI. Prosiding Seminar Nasional Pengembangan dan Pemanfaatan IPTEK untuk KEdaulatan Pangan. Yogyakarta. Fakultas Pertanian Universitas Gadjah Mada.

Direktori Sumber Daya Energi, Mineral dan Pertambangan. (2012). Policy Paper Keselarasan Kebijakan Energi Nasional (KEN) dengan Rencana Umum Energi Nasional (RUEN) dan Rencana Umum Energi Daerah (RUED). Jakarta. Badan Perencanaan Pembangunan Nasional.

Galvez, D., Rakotondranaivo, A., Morel, L., Camargo, M., \& Fick, M. (2015). Reverse logistics network design for a biogas plant: An approach based on MILP optimization and Analytical Hierarchical Process (AHP). Journal of Manufacturing Systems, 37, 616-623.

Gebreegziabher, Z., Naik, L., Melamu, R., \& Balana, B. B. (2014). Prospects and challenges for urban application of biogas installations in Sub-Saharan Africa. Biomass and bioenergy, 70, 130-140. 
Havukainen, J., Uusitalo, V., Niskanen, A., Kapustina, V., \& Horttanainen, M. (2014). Evaluation of methods for estimating energy performance of biogas production. Renewable energy, 66, 232-240.

Ministry of Energy and Mineral Resources Republic of Indonesia. (2014). Handbook of Energy and Economic Statistic of Indonesia. Jakarta. PUSDATIN ESDM.

Setyawan, A.H. (2010). Pengembangan Biogas Berbahan Baku Kotoran Ternak Upaya Mewujudkan Ketahanan Energi di Tingkat Rumah Tangga. Bandung. Institut Teknologi Bandung.

Waskito, D. (2011). Analisis Pembangkit Listrik Tenaga Biogas dengan Pemanfaatan Kotoran Sapi di Kawasan Usaha Peternakan Sapi. Thesis. Jakarta. Universitas Indonesia. 